Trivent Publishing

(C) The Authors, 2016

Available online at http://trivent-publishing.eu/

\title{
The Transcendental Character of the Eternal Recurrence of the Same
}

\author{
Monica Fetico \\ West University of Timisoara, Romania
}

\begin{abstract}
The eternal return may be interpreted as a transcendental notion and, therefore, as a possible condition for the other key concepts in Nietzsche's philosophy.

Based on this, I intend to link the eternal recurrence of the same to the Kantian theory of perception as described in Critique of Pure Reason ${ }^{1}$, and to the categorical imperative. Before doing so, this paper will emphasize that the eternal return was made possible by conveying the message of the death of God. Hence, there are three hypotheses which need to be discussed:

1. The eternal recurrence of the same is possible in Nietzsche's philosophy only by admitting that God is dead.

2. The eternal return is a necessary condition for lived experience. Here, I will consider the common aspects of the eternal recurrence and the a priori intuition of time presented in Kant's transcendental aesthetic as a priori forms of the intuitions belonging to the subjective constitution of the human mind.

3. The eternal recurrence holds the value of a categorical imperative.

The aim of this paper is to argue the fact that the eternal recurrence of the same is a universal and necessary condition for the lived experience It is, therefore, a transcendental principle in Nietzsche's philosophy.
\end{abstract}

\section{Keywords}

Eternal recurrence; transcendentalism; categorical imperative; will; death of God.

\footnotetext{
${ }^{1}$ Immanuel Kant. Critique of the Pure Reason, trans. Paul Guyer and Allen Wood, Cambridge University Press, February 1999.

This is an Open Access article distributed in accordance with the Creative Commons Attribution Non Commercial (CC-BYNC-ND 4.0) license, which permits others to copy or share the article, provided original work is properly cited and that this is not done for commercial purposes. Users may not remix, transform, or build upon the material and may not distribute the modified material (http://creativecommons.org/licenses/by-nc/4.0/) 


\section{Introduction}

The eternal recurrence of the same is often seen as the central element of Nietzsche's philosophy. This is a controversial subject due to its apparent contradiction with other key concepts of the German philosopher's thought, as the will to power or the superman. However, the will to power and the superman may be regarded as consequences of the eternal recurrence, if the latter is interpreted as a transcendental notion and, therefore, as a possible condition for the other key concepts. I propose that the eternal recurrence may be understood as a transcendental ground, especially if we analyze the famous depictions of this concept in two major works belonging to Friedrich Nietzsche: The Gay Science $^{2}$ and Thus spoke Zarathustra. ${ }^{3}$ In order to demonstrate my point of view, I will do a comparative analysis of the two descriptions with the a priori intuition of the time, as it appears in Kant's transcendental aesthetics, and with the categorical imperative, respectively. This way, I will emphasize some aspects that the eternal recurrence and these Kantian concepts have in common, trying to show the perspective from which the eternal recurrence can be understood as a transcendental principle.

Before starting this analysis, it must be mentioned that I will use the terms "eternal return" and "eternal recurrence" as equivalents. Furthermore, I will also use the terms "overman" and "superman," as names representing Nietzsche's Ubermensch.

\section{The death of God: the premise of the eternal return}

The message of the death of God is delivered in Friedrich Nietzsche's work The Gay Science, through the Madman's voice ${ }^{4}$. Of course, such a terrific event is very hard to acknowledge, and this is probably why the German philosopher chose a mad man to deliver this message. Nevertheless, this event cannot be hidden as Nietzsche compares its obviousness to the odor of a corpse. Through the madman's voice, Nietzsche asks the others several questions while asking himself at the same time: how was this crime committed, with whose permission, with what kind of strength, and how can this crime be justified? So, there is a crime, but no one can identify the murderer, the corpse, or even the date and time of the event. In Jean Luc Marion's opinion, it is very important that the messenger himself is unable to know how the crime he denounces took place. The lack of the spatial and temporal coordinates, as Marion notices, means that the death of God is a collective event and everyone across time and space participates in this criminal act ${ }^{5}$. In Tongeren's opinion, another noteworthy aspect is that Nietzsche frames this message in the form of a parable. The fact that Nietzsche uses such a style of the writing used also in the Bible can be interpreted as Nietzsche wanting to establish a new history of mankind. ${ }^{6}$

\footnotetext{
${ }^{2}$ Friedrich Nietzsche, Die fröhliche Wissenschaft, KSA 3: Friedrich Nietzsche: Sämtliche Werke. Kritische Studienausgabe, 2nd edn., ed. Giorgio Colli and Mazzino Montinari, 15 vols. (Berlin and New York: de Gruyter, 1988)

${ }^{3}$ Friedrich Nietzsche, Also sprach Zarathustra, KSA 4: Friedrich Nietzsche: Sämtliche Werke. Kritische Studienausgabe, 2nd edn., ed. Giorgio Colli and Mazzino Montinari, 15 vols. (Berlin and New York: de Gruyter, 1988)

${ }^{4}$ Fr. Nietzsche, The Gay Science. trans. Walter Kaufmann, (Vintage, 1974), 181-182.

${ }^{5}$ J.L. Marion, Idolul şi Distanţa [The Idol and the Distance] (Bucharest: Humanitas, 2007), 57.

${ }^{6}$ P.J.M. Tongeren, Reinterpretarea culturii moderne. O introducere în filosofia lui Friedrich Nietzsche [An Introduction to Friedrich Nietzsche's philosophy] (Târgu-Lăpuş: Galaxia Gutenberg, 2004), 292.
} 
According to Nietzsche, one thing that determined the death of God is pity. ${ }^{7}$ Gilles Deleuze relates this emotion to nihilism ${ }^{8}$, specifically reactive nihilism. In the reactive nihilism phase, transcendence, the first form that helps the nihilist to negate life, is rejected; but since nihilism alone cannot create new values, the immanence permeating life continues to be depreciated and emptied of any purpose or value. Since both transcendence and immanence are now rejected, the nihilist opts for nothing instead. In this way, Nietzsche explains that God was killed due to the pity he felt towards the weak character of the reactive human. ${ }^{9}$

Another cause of God's death is the desire to gain knowledge about him. Deleuze declares that "God is dead!" is a dramatic sentence that escapes the limits of binary logic. Therefore, this is not an analytic sentence, but instead it claims to be a synthetic one which imparts new knowledge. ${ }^{10}$ The same interpretation is adopted by Jean Luc Marion. He considers that the image depicted by Nietzsche in The Gay Science of the madman holding a light and crying out that he searches for God can be related to the image of an idol hidden within the obscurity of a sacred temple. It is only when the idol is concealed within the walls of the temple does it represent a sacred being; but if it is taken outside into the light, the mystery is removed and it becomes just a lifeless statue. ${ }^{11}$ So, according to Marion the divinity of God is suppressed twice: first, when God became an idol (the idol of the fictional values of the transcendence, therefore an illusion), and second, when the transcendence is rejected and the idol becomes just a concept.

To Friedrich Nietzsche, the death of God means rejecting any universal law, any absolute truth and all traditional values, risen by the slave type of people, driven by reactive forces, with the tools of nihilism: resentment, bad conscience and ascetic ideals. In this way, the German philosopher wants to destroy the traditional metaphysics that undervalue life, proclaiming the supremacy of transcendence. I believe this revolutionary attitude is similar to Immanuel Kant's critique of traditional metaphysics, even though the two philosophers have a different purpose and approach. Kant also wants to exclude transcendent ideas (for instance, the Idea of a Supreme Being) because they cannot be known through sensory receptivity or intellectual thought and thus it cannot be explained through the synthetic process. God, as the ideal of pure reason, can serve as a regulative idea, but Kant notices that this formal construct is often mistaken as an actual entity or metaphysical ground for all that it is. ${ }^{12}$

For Nietzsche, the importance of the message that God has died means that it is absolutely necessary to create a new axiological order that is free from the traditional, decadent one. Through this order, life must regain its positive value and in order for this to happen, one must have the strength to become a god himself. This is only possible by admitting the crime; this means disavowing the passivity of a witness to the event, a situation illustrated by the sentence "God is dead", and instead acknowledging oneself as the murderer involved in the act, i.e. "We have killed him." ${ }^{13}$ So, the negative nihilism, represented by the supremacy of the transcendence, and its consequence, the reactive nihilism, represented by the rejection of this transcendence, can only be overcome by the Overman that wants the eternal return. In sum, the teaching of the eternal recurrence is the solution to

\footnotetext{
${ }^{7}$ Fr. Nietzsche, Thus spoke Zarathustra in: 'The Portable Nietzsche', trans. Walter Kaufmann (Penguin: 1977), $73,205$.

${ }^{8}$ There are three types of nihilism in Nietzsche's philosophy: negative, reactive, and passive. For further reading, please see Gilles Deleuze book, Nietzsche and Philosophy, Columbia University Press, 2006.

${ }^{9}$ G. Deleuze, Nietzsche şi filosofia [Nietzsche and Philosophy] (Bucharest: Ideea Europeana, 2005), 173.

${ }^{10}$ Ibidem, 176.

${ }^{11}$ J.L. Marion, The Idol and the distance, 58-60.

${ }^{12} \mathrm{Imm}$. Kant, Critique of the pure reason, trans. Paul Guyer and Allen Wood (Cambridge: Cambridge University Press, 1998), 557-559.

${ }^{13}$ P. Fritzsche, Nietzsche and the Death of God: Selected Writings (Illinois: Waveland Press Inc., 2013), 10.
} 
the problem of nihilism stemming from the death of God. ${ }^{14}$ An individual transformed like this must overcome him/herself, so one must become their own creator and, in this way, the creator of an entire world. This sort of human being can be none other than the Overman and this sort of creation can be made only in the frame of the eternal recurrence. Therefore, we can assume that by admitting the death of God, the linear, finalist view of the world is overthrown and is thus replaced by a more complex view, one that says an eternal "yes" to life which is free from transcendence.

\section{The a priori intuition of time and the eternal recurrence}

Even though Nietzsche mentioned the possibility of an eternal return in his early writings (in Untimely Meditations, for example) he explicitly discusses the eternal recurrence of the same in the 341th paragraph of The Gay Science:

The greatest weight. - What, if some day or night a demon were to steal after you into your loneliest loneliness and say to you: 'This life as you now live it and have lived it, you will have to live once more and innumerable times more; and there will be nothing new in it, but every pain and every joy and every thought and sigh and everything unutterably small or great in your life will have to return to you, all in the same succession and sequence -- even this spider and this moonlight between the trees, and even this moment and I myself. The eternal hourglass of existence is turned upside down again and again, and you with it, speck of dust!' Would you not throw yourself down and gnash your teeth and curse the demon who spoke thus? Or have you once experienced a tremendous moment when you would have answered him: 'You are a god and never have I heard anything more divine'? If this thought gained possession of you, it would change you as you are, or perhaps crush you. ${ }^{15}$

We notice that Nietzsche advances the idea of the eternal return as a hypothesis, i.e. an experimental thought. The messenger that brings this idea may be perceived either as a demon or as a god, depending of the inner strength of the individual recipient. A weak human, one that lives according to the moral ideas of the herd, will be unable to bear this thought because for such a human being life has no inherent value and the purpose of the existence is thus found elsewhere, be it in the afterlife or a transcendent realm. In this way, only the Overman will have the willpower to receive this news and desire the eternal return. We will return to the analysis of this paragraph later, after discussing another essential excerpt regarding the eternal recurrence of the same in Thus spoke Zarathustra.

In a sub-heading of Zarathustra, "On the vision and the riddle," ${ }^{16}$ Nietzsche advances the discussion about the eternal recurrence in the form of a riddle. The main character tells a story of where he climbs up a mountain, but his steps are slowed down by a dwarf clinging onto him; Zarathustra associates this dwarf with "the spirit of gravity", a symbol for the nihilist type of human. The dwarf taunts Zarathustra, saying that no matter how far into the sky you throw a stone, it will necessarily fall back to earth. Zarathustra then faces the dwarf with courage, called by him "the best slayer" and the pride of humanity, as the element that defies all the abysses and even death, the courage that one must have in order to encounter even the deepest suffering. Courage is also required

\footnotetext{
${ }^{14} \mathrm{~K}$. Löwith, Nietzsche's philosophy of the eternal recurrence of the same (London: University of California Press, 1997), 55.

${ }^{15}$ Fr. Nietzsche, The Gay Science (English translation by Walter Kaufmann), 401-402.

${ }^{16}$ Fr. Nietzsche, Zarathustra, ed. cit., 124-127.
} 
for one that acknowledges him/herself as the murderer of God, therefore courage is needed for overcoming one's limits. Only by having this courage can the individual become what Nietzsche calls the Overman. Therefore, courage is vision. Zarathustra then offers an image: a gate named "moment" which is the meeting point of two contradictory eternities. He wonders and asks the dwarf: what if those two never-ending ways fought forever? The dwarf rejects these "straight things" as lies, saying time itself is a circle. Nonetheless, Zarathustra continues by saying that everything that was will be again, everything that happened will happen again and all those recurring things must pass through the gate named "moment," but the gate itself was there before and will be again, so the gate carries everything and, at the same time, carries itself. Scared, the dwarf disappears and is replaced by a howling dog, then by a shepherd with a snake hanging from his mouth, who turns into a bright, laughing being after he bites off the head of that snake.

The three apparitions at the end of this story are each symbols for Nietzsche's ideas. Paul Loeb considers the howling dog and the gagging shepherd to represent Zarathustra's failure in teaching the humans about the Superman, to be their shepherd, or at least a failure to warn humanity about the lasthuman ${ }^{17}$. However, one possible interpretation is to link these two previsions with the death of God itself. In this regard, the howling dog may be seen as the messenger of the death of God, while the shepherd bitten by the snake may represent the people that feel lost in a void and empty world. These are humans who might succumb to nihilism: the bad conscience, ressentiment, and the ascetic ideal that continuously attacks them the same way that the snake bites the shepherd. But, just as the shepherd bites the snake back, freeing himself, every other individual must gather courage to destroy the older idols and to become an Overman in this way. This act itself, the shepherd biting the head of the snake that bites him, forms a circle, a symbol of the eternal recurrence of the same.

We can assume that the eternal return is necessary to live an authentic life, and thus a condition for the affirmation of life itself. Thus, we can read Nietzsche's text on the eternal recurrence with Kant's framework in mind, considering that the eternal return is somewhat similar to the a priori intuition of the time itself. This description is very similar to the metaphysical exposition ${ }^{18}$ of the concept of time in Critique of Pure Reason. First, as time is not an empirical concept (since successive events cannot be derived from any given experience) the eternal return, as depicted by Nietzsche in the cited fragments from Zarathustra and The Gay Science, is not empirical either, but an experiment in thought. Second, time itself cannot be removed from the given experience of the subject, while all the determinations of the phenomena can be removed, and yet the subject can still represent for himself time, as the foundation of its intuitions. We can only understand phenomena in its relationship to time, which means time is the universal possibility for the phenomena. Therefore, time is an a priori intuition. Similarly, everything that was or will be is possible within the frame of that gate named "moment," the meeting point of the two infinite and eternal roads. Other things and even the two roads themselves can be reduced to that one gate representing the eternal return. Another similarity of the a priori intuition of time and the eternal recurrence is that, according to Kant, different times are still part of one and the same time, so time itself is not a discursive concept, but an intuition because the representation that can be given only by a singular object is called an intuition. In Vision and the riddle, the two roads symbolizing the past and the future are also part of the same time, symbolized by the gate named "moment;" the different times are also represented by the meeting-gate. That gate is the vision of the eternal recurrence, and therefore we can infer that the eternal recurrence is an intuition.

\footnotetext{
${ }^{17}$ P.S. Loeb, The death of Nietzsche's Zarathustra (New York: Cambridge University Press, 2010), 184.

${ }^{18} \mathrm{Imm}$. Kant, Critique of Pure Reason, ed.cit., 178-179.
} 
In his transcendental exposition of the concept of time, ${ }^{19}$ Kant explains how the concept of alteration and the concept of motion are possible only through and in the representation of time. Time, therefore, is an a priori intuition which can give synthetic knowledge. Kant also emphasizes that two contradictory objects can exist in the same place only in the representation of time, due to successive evets. Compared to the vision of Zarathustra, we notice how the character says that everything and everyone passes through those two roads and the contradictory roads can all meet in one place: the gate. So, every change and every movement is done within the framework of the eternal recurrence.

Another similarity can be found in Kant's notion that time is not something that exists in and of itself, nor is it something that is inherent to an external object; time does not remain if all the subjective conditions of the intuition are made abstract. Time is the form of the inner sense, meaning that the intuition of our inner state stays for the period in between our inner representations. Similarly, the eternal return is not an external occurrence but rather an intuition of the subject itself. We can assume that, as well as time, the eternal return is an a priori form, it therefore has no real shape and is represented by analogies: namely through the analogy of the two linear roads and the gate. Also, no object can be given in experience without conforming itself to the condition of time, ${ }^{20}$ just as everything must be given within the frame of the eternal recurrence for the subject to perceive it. Therefore, eternal recurrence does not have external, absolute reality, but it is an experience dependent on the subject. Since it is not inherent or subsistent for the objects, but to the inner representations of the subject, thus time has transcendental ideality and so does the eternal return, as an experience that depends on the perceiving subject.

\section{The imperative side of the eternal recurrence}

If the description of the eternal recurrence in Nietzsche's Thus spoke Zarathustra can be compared with Kant's exposition of the a priori intuition of time, we can thus identify similarities between the paragraph from Gay Science and the categorical imperative.

In Gay Science, the German philosopher tries the aforementioned thought experiment, advancing the idea about the eternal return in the form of a message delivered by a demon asking his listener what if one must live life innumerable times over and over. For this demon to become a god instead, one must overcome him/herself and then become the Overman, whose will is strong enough to actually want the eternal recurrence of the same. This message clearly has an imperative character, but we need to see how this resembles the categorical imperative.

Kant gives three major formulations (with two variants) ${ }^{21}$ for moral law in his Groundwork for the metaphysics of morals, but here we are interested only in two of these: the formula of the universal law (FUL) and the formula of the realm of ends (FRE). "Act only in accordance with that maxim through which you can at the same time will that it become a universal law"22 is the formulation of the first, while the second is "Act in accordance with maxims of a universally legislative member for a merely possible realm of ends." 23

\footnotetext{
${ }^{19} \mathrm{Imm}$. Kant, Critique of Pure Reason, ed. cit., 179.

${ }^{20}$ Ibidem, 83.

${ }^{21}$ The first and third each have a variant. For a detailed list, see Formulations of the moral law in Imm. Kant, Groundwork for the metaphysics of morals (Yale University, 2002), edited and translated by Allen W. Wood.

${ }^{22} \mathrm{Imm}$. Kant, Groundwork for the metaphysics of morals (Yale University Press, 2002), edited and translated by Allen W. Wood., 38.

${ }^{23}$ Ibidem, 57.
} 
We are aware that, for Nietzsche, the eternal recurrence of the same lacks a moral implication. What we wish to prove here is that the eternal recurrence has the same strength as the categorical imperative and that this idea from Nietzsche can be universalized. For Nietzsche's readers, one can assume that it is already obvious from the author's idea of the Overman that free-will and the eternal recurrence is something that should be adopted by everyone. This is evident from his alter-ego Zarathustra going to the marketplace to teach this doctrine to all the people. Also, by acknowledging that the death of God is the premise of the eternal recurrence we see that the one that overcomes him/herself is, in Nietzsche's terms, a god and thus the creator of a world. This creator creates, so he acts according to his own will to power which is essentially a creative force. ${ }^{24}$ The world he creates must conform to the eternal recurrence to be an authentic one and if it is not authentic, then it belongs to the slave type and the whole discussion makes no sense. So the eternal recurrence is the condition that determines the act of creation, just as the moral law is the condition that determines the actions of the rational subject ${ }^{25}$. Therefore, even though Nietzsche's language is very metaphorical, I think that in this regard the eternal recurrence can be compared to the formula of Kant's universal laws.

As for the formula of the realm of the ends, we notice that Nietzsche also thinks in terms of an authentic world in which the will to power manifests itself creatively and all of the individuals within have accomplished the act of overcoming their limited nature. As mentioned in Kant's moral philosophy, reason must dominate empirical inclinations, Nietzsche likewise states that a man should acquire self-control over his own impulses rather than reject or destroy them; otherwise the respective human is weak. ${ }^{26}$ According to Walter Kaufmann, those impulses are designated by Nietzsche through the term "chaos" and this chaos must be organized in order for the human being to acquire harmony. The method Nietzsche advocates is sublimation, meaning the channeling of impulses towards creative acts. Kaufmann emphasizes that the organic harmony gained this way generates an ontological harmony. ${ }^{27}$

Another reference to the realm of the ends may be found in Nietzsche's Untimely Meditations ${ }^{28}$. In the second Meditation, Friedrich Nietzsche is talking about the supra-historical point of view, a dimension in which history cannot bring any new knowledge because everything that will be once was. The purpose of history at this point is not at an end, but occurring at every moment through the superior representatives. Kaufmann identifies this conception as the ground for the theory about the eternal recurrence, ${ }^{29}$ and he also links it to the conception about the Overman as there is no inconsistency between those two theories since one is necessary for another to happen and vice versa.

Lastly, linking the eternal recurrence and the Overman with the joy of amor fati, these elements offer a supra-historical look over the world as a perfect realm. ${ }^{30}$ In this world, life gains its supreme affirmation since every moment has absolute value rather than infinite progress or a state of evolution. I consider that this perfect world, the realm of the Overman, is a realm made possible by embracing the eternal recurrence. It can be seen as the correspondent of the realm of the ends, where moral agents can freely exercise their moral law, seeing in each other ends rather than means.

Of course, there are objections to such interpretations and one of the most vocal is given by Walter Kaufmann himself. Kaufmann specifically warns that the eternal recurrence should not be thought of

${ }^{24}$ W. Kaufmann, Nietzsche: Philosopher, Psychologist, Antichrist (Princeton: Princeton University Press, 1974), 250.

${ }^{25} \mathrm{Imm}$. Kant, Critique of Pure Reason, 479.

${ }^{26} \mathrm{~W}$. Kaufmann, Nietzsche, 224.

${ }^{27}$ Ibidem, 227.

${ }^{28}$ Friedrich Nietzsche, Untimely Meditations, trans. R.J. Hollingdale, Cambridge University Press, 1997.

${ }^{29}$ W. Kaufmann, Nietzsche, 319.

${ }^{30}$ Ibidem, 321. 
as a construction similar to the categorical imperative since Kant did not mean to appeal to humanity's psychological disposition, but only to lay the ground for the maxim of an action, avoiding contradiction. He also emphasizes that Nietzsche was not primarily a moral philosopher. ${ }^{31}$ Nevertheless, Nietzsche does not completely overlook the moral side of the human nature. Moreover, what matters the most in this situation is not the moral use of the imperative, but the strong character of such a rule and the possibility of universalizing. I consider that we may call the eternal recurrence an existential imperative without losing its coercive strength.

To summarize, we may understand the death of God as a pre-condition for the eternal recurrence; this eternal recurrence is the frame within which the Overman can creatively manifest his/her will to power. The eternal recurrence is not a real temporal dimension since it depends on the subject's conscience. However, the eternal recurrence is not a mental construct, but rather an intuition, similarly as time is an a priori intuition of the self, manifested in the form of the inner senses. The eternal recurrence also has a coercive influence over the subject, determining its actions just as the categorical imperative guides the actions of the moral agent in Kantian moral philosophy. Therefore, we can assume that the eternal recurrence has a transcendental character, being the condition of possibility for the overman and, implicitly, for the will to power.

\section{References}

Deleuze, Gilles. Nietzsche and Philosophy, Bucharest: Ideea Europeana, 2005.

Fritzsche, Peter. Nietzsche and the Death of God: Selected Writings. Illinois: Waveland Press Inc., 2013.

Kant, Immanuel. Critique of the pure reason, trans. Paul Guyer and Allen Wood, Cambridge University Press, 1998.

Kant, Immanuel. Groundwork for the metaphysics of morals. Yale University, 2002.

Kaufmann, Walter. Nietzsche: Philosopher, Psychologist, Antichrist. Princeton: Princeton University Press, 1974.

Loeb, Paul. The death of Nietzsche's Zarathustra. New York: Cambridge University Press, 2010.

Löwith, Karl. Nietzsche's philosophy of the eternal recurrence of the same. London: University of California Press, 1997.

Marion, Jean Luc. The Idol and Distance, Bucharest: Humanitas, 2007.

Nietzsche, Friedrich. The Gay Science. trans. Walter Kaufmann, Vintage, 1974.

Nietzsche, Friedrich. Thus spoke Zarathustra in: 'The Portable Nietzsche', trans. Walter Kaufmann, Penguin, 1977.

Tongeren, Paul. Reinterpreting modern culture. An Introduction to Friedrich Nietzsche's philosophy. Târgu-Lăpuş: Galaxia Gutenberg, 2004.

\section{Acknowledgements}

This work was co-financed from the European Social Fund through the Sectoral Operational Programme Human Resources Development 2007-2013, project number POSDRU/187/1.5/S/155559, Competitive Multidisciplinary Doctoral Research in Europe.

\footnotetext{
${ }^{31}$ Ibidem, 322.
} 